\title{
Survey of Pigeon Pea Wilt Caused by Cyst Nematode (Heterodera cajani) in Trans Yamuna and Ganga Taluks of Allahabad District, India
}

\author{
Amit Kumar Maurya*, Sobita Simon, Vinny John and Abilasha A. Lal \\ Department of Plant Pathology, Sam Higginbottom University of Agriculture, Technology and \\ Sciences, Allahabad (U.P.) - 211 007, India \\ *Corresponding author
}

A B S T R A C T

\begin{tabular}{|l|}
\hline Ke y w or d s \\
Heterodera cajani, \\
Pigeon pea, Cysts \\
\hline Article Info \\
\hline $\begin{array}{l}\text { Accepted: } \\
\text { 04 May } 2018 \\
\text { Available Online: } \\
\text { 10 June } 2018\end{array}$ \\
\hline
\end{tabular}

\section{Introduction}

Pigeon pea [Cajanus cajan (L.) Mills.], a pulse crop of Indian origin is a major source of protein in the world's vegetarian diet. Belongs to family Fabaceae. It is the most important kharif pulse crop with much higher productivity. World production of pigeon peas is estimated at 4.3 million tons ${ }^{2}$. About $82 \%$ of this is grown in India. In India, South Asia and in remaining world, it is consumed as 'Dal' or Sambhar and is an important item in the vegetarian menu.

India is the largest producer, $25 \%$ of world's production, and consumer $27 \%$ of total pulses of the world. The domestic production is often less than the estimated demand i.e. 23-24 million tons. Studies on consumption pattern has revealed that in India only 8-10 million tons of pulses are used directly as a food item (Dal), the remaining 12 million tons being indirect actual consumption as processed/value added products such as snacks, fast food for domestic consumption and export.

Pigeon peas contain high levels of protein and the important amino acids methionine, lysine and tryptophan.

It now occurs in all the major pigeon pea producing states of India i.e. Andhra Pradesh, Bihar, Gujarat, Haryana, Karnataka, Maharashtra, Punjab, Rajasthan, Tamil Nadu and Uttar Pradesh. It is particularly 
widespread on sandy loams in Northern India and vertisols of Southern India (Sharma et al., 1992).

Pigeon pea is affected by various diseases caused by fungus, bacteria, nematode and viruses. Wilt is one of the most prominent diseases of pigeon pea and can cause losses up to 30 to $40 \%$. The crop has been reported to suffer severe damage due to wilt disease caused by Heteodera cajani and Fusarium udum complex (Koshy and Swamp, (1971); Sikora and Greco, (1990); Ali and Askary, (2001). Nematodes are widely distributed in most of the pigeon pea growing regions in India. Pigeon pea is vulnerable to many plant parasitic nematodes viz., Meloidogyne spp., Heterodera cajani, and root knot nematode (M. javanica) and pigeon pea cyst nematode (Heterodera cajani) are the most important parasites.

Some 70 genera and 160 species of fungi have been found associated with nematodes (Qadri, 1989).The main symptoms of an $H$. cajani infection are stunted growth and reduced yield due to damage to the host plants root system. Flowers and pods are reduced in size and number and the root system may also be poorly developed.The main objective of this survey was to estimate and observe the wilt incidence and their association with cyst nematode.

\section{Materials and Methods}

A roving field survey was conducted in 15 villages of trans Yamuna taluks (Table 1) and 10 villages of trans Ganga taluks (Table 2) of Allahabad districts. About 45 days old crop was taken into consideration. 5 fields from each villages and 3 villages from each blocks were surveyed. The sample were collected /drown from the rhizosphear region of five or more stunted plants at random in each field. Each sample consisted of $250 \mathrm{~g}$ of soil and the soil was mixed thoroughly and $500 \mathrm{~g}$ of soil was collected and cob's sieving and shifting techniques was followed for further nematode extraction. (Thorne, 1961)

\section{Calculation of disease incidence (DI)}

The percent disease incidence of wilt disease was calculated by using the formula:

Disease incidence $\%=\frac{\text { Total no. plants wilted }}{\text { Total no. of plants examined }} \times 100$ (Trapero-casas, 1983).

\section{Results and Discussion}

The intensive roving survey was conducted in 15 pigeon pea growing villages of trans Yamuna taluks of Allahabad district during rabi season of 2016. The occurrence of important genra $H$. cajani associated with rhizosphere of pigeon pea. The below table 1 shows that $H$. cajani was observed with minimum of 14 cysts in Panwar followed by Karchhana (18) to a maximum of 51 cysts in Kuan followed by Telghana (41) per $500 \mathrm{~g}$ of soil. In a intensive roving survey conducted in 10 pigeon pea growing villages of trans Ganga taluks of Allahabad district during rabi season of 2016, minimum of 18 cysts per $500 \mathrm{~g}$ of soil were found in Hardaun followed by 23 cysts in Mandav. Maximum cysts were found in the soil sample of Mairi (35) followed by Mohrub (33). Over all highest larva population was found in Telghana (664) followed by Dera (659) as shown in table 2 . The symptoms produced were identical to those described earlier by Singh and Singh (1990) reported distribution of $H$. cajani from the different pigeon pea growing areas of Varanasi and Mirzapur of Uttar Pradesh. Similarly Devi (1994) and Sharma and Trivedi (1994), Devappa V and S Lingaraju (2011) reported $H$. cajani, Rotylenchulus reniformis and Meloidogyne. 
Table.1 Survey on the incidence of cyst nematode (Heterodera cajani) of pigeon pea in 15 villages of trans Yamuna talukas of Allahabad district during 2016

\begin{tabular}{|c|c|c|c|c|}
\hline District & Taluka & Village & $\begin{array}{l}\text { No. of cyst / } \\
500 \mathrm{~g} \text { soil }\end{array}$ & No. of larvae \\
\hline \multirow[t]{15}{*}{ Allahabad } & \multirow[t]{6}{*}{ Bara } & Kanti & 28 & 250 \\
\hline & & Amreha & 30 & 353 \\
\hline & & Ojhapatti & 35 & 556 \\
\hline & & Dera & 38 & 659 \\
\hline & & Telghana & 41 & 664 \\
\hline & & Newariya & 19 & 239 \\
\hline & \multirow[t]{9}{*}{ Karchhana } & Hathigan & - & - \\
\hline & & Chaka & 39 & 461 \\
\hline & & Mahuari & 37 & 579 \\
\hline & & Kuan & 51 & 670 \\
\hline & & Gaura & - & - \\
\hline & & Panwar & 14 & 178 \\
\hline & & Karchhana & 18 & 153 \\
\hline & & Ghatwa & - & - \\
\hline & & Naraina & 29 & 347 \\
\hline
\end{tabular}

Table.2 Survey on the incidence of cyst nematode (Heterodera cajani) of pigeon pea in 10 villages of trans Ganga talukas of Allahabad district during 2016

\begin{tabular}{|c|c|c|c|c|}
\hline District & Taluka & Village & $\begin{array}{l}\text { No. of cyst / } \\
500 \mathrm{~g} \text { soil }\end{array}$ & No. of larvae \\
\hline \multirow[t]{10}{*}{ Allahabad } & \multirow[t]{6}{*}{ Koraon } & Dhus & 26 & 294 \\
\hline & & Hardaun & 18 & 287 \\
\hline & & Mandav & 23 & 307 \\
\hline & & Sirawal & - & - \\
\hline & & Tikar & 27 & 321 \\
\hline & & Usari & 29 & 328 \\
\hline & \multirow[t]{4}{*}{ Soraon } & Gaura & 31 & 347 \\
\hline & & Mairi & 35 & 482 \\
\hline & & Mohrub & 33 & 397 \\
\hline & & Rohi & - & - \\
\hline
\end{tabular}

\section{References}

Ali, S.S. and Askary, T.H. (2001). Taxonomic status of nematodes of pulse crops. In: nematode taxonomy concepts and Recent Trends. Eds. M.S. Jairajpuri and P.F. Raharnan, LQ. Printers,
Hyderabad, India, 197216 pp. Annals of Plant Protection Science, 2: 85-86.

Devappa V and S Lingaraju (2011). Survey for incidence of pigeon pea cyst nematode Heterodera cajani on minor pulses from different pulse growing 
areas of Karnataka. Bioscience Discovery. 2(1): 2229-3469.

Devi. L S. (1994). Survey of some endoparasitic nematodes and wilt fungi associated with pigeon pea.

Koshy, P. K. and Swarup, G. (1971). Distribution of Heteroderaavenae, $H$. zeae, $H$. cajani and Anguinatritici in India. Indian J. Nematol. 1: 106-111.

Qadri, A. N. (1989). Fungi associated with sugar beet cyst nematode in Jerash Jordan. M.Sc Thesis, University of Jordan.

Sharma, S. B., Smith, D. H., Mc. Donald, D., (1992). Nematode constraints of chickpea and pigeon pea production in the semi-arid tropics.Plant Disease, 76: 868-874.
Sikora, R. A. and Greco, N. (1990). Nematode parasites of food legumes. In: Plant parasitic nematodes in subtropical and tropical agriculture. Eds. M. Luc, R.A. Sikora and Bridge. CAB Inter., V.K. pp. 181235.

Singh V K and Singh K P. (1990). Population density of Heterodera cajani in Varanasi and Mirzapur. Lndian Journol of Nematol. 2: 2-222.

Thorne G. (1961). Principles of Nematology, McGraw Hill Book Co. Inc. New York: 553.

Trapero-Casas, A. and Jimenez-Diaz, R.M. (1983). Fungal wilt and root rot diseases of chickpea in southern Spain. Physiopathology, 75: 1146-1151.

\section{How to cite this article:}

Amit Kumar Maurya, Sobita Simon, Vinny John and Abilasha A. Lal. 2018. Survey of Pigeon Pea Wilt Caused by Cyst Nematode (Heterodera cajani) in Trans Yamuna and Ganga Taluks of Allahabad District, India. Int.J.Curr.Microbiol.App.Sci. 7(06): 799-802. doi: https://doi.org/10.20546/ijcmas.2018.706.093 